during chloroform anæsthesia they described a new form of plethysmograph suitable for use with cats.

In 1910, Buckmaster and Gardner were led to devise a new form of blood gas pump without taps or joints and ending in barometers, thus being entirely leak-proof. It was described in the Journal of Physiology, 1910, and in the same journal were published papers on the nitrogen content of blood, the gases in arterial and venous blood of cats, the composition of the blood gases in chloroform anæsthesia, and the composition of the blood gases during the respiration of oxygen.

While at Bristol, Buckmaster and Dr. Hickman made use of the same pump in an exhaustive investiga. tion of the body fluids other than blood, particularly bile and urine.

Socially, Buckmaster was a delightful man. His superb memory, his wide knowledge of literature and his fund of stories of men and things made him an interesting and fascinating talker, while his deep sense of humour, his wit and his kindly loyalty of disposition endeared him to all who had the privilege of his friendship.

J. A. G.

\section{Prof. Alfred Lodge}

Alfred Lodge, who died at Oxford on December 1 of last year, so far outlived his contemporaries that it is scarcely possible now to see him through their eyes. Born in 1854, educated at Horncastle Grammar School and Magdalen College, Oxford, he was elected to a Fereday fellowship at St. John's College, Oxford, in 1876, and appointed in 1884 to the staff of the Royal Indian Engineering College, Coopers Hill, where he presently succeeded Wolstenholme as professor of pure mathematics ; on the dissolution of the College in 1904 he became a master at Charterhouse, and there he remained until after the Great War.

Lodge's work in mathematics was all of the most elementary kind, but he was an enlightening teacher and a tireless computer. As a teacher he was active in the Association for the Improvement of Geometrical Teaching, and when that society broadened its basis to become the Mathematical Association, he was appropriately the first president to bear the new title; to the end of his life he was a familiar figure at the meetings of the Association.

As a computer, Lodge was a member for fifty years of the British Association Committee on mathematical tables, and it is in the publications of that Committee that his name will survive; if he did little to improve the technique of computing, he laboured incessantly in the practice, and work of his is incorporated in many of the reports, in the volume of miscellaneous tables published in 1931, in a factor table published in 1935, and in a volume of tables of Bessel functions which has just appeared ; in addition to computing, he took a willing share in the discussions of the Committee and in the toil of proofreading.

Sir Oliver Lodge writes of his brother, "He was . . . always willing to slave away in the background. . . . I have many dim recollections of his willing selfsacrifice for the family in early days". He was a secretary of Section A (Mathematical and Physical Sciences) of the British Association from 1888 until 1892, and from 1893 until 1896 he was recorder of the Section, a position so unusual for a mathematician that his appointment must be taken as a tribute to the confidence which he inspired; he served on the Council of the British Association from 1913 until 1915. The volume of tables of Bessel functions which has been mentioned is "Inscribed to their friend Alfred Lodge by his colleagues on the Committee" as a token of the warmest affection. These glimpses, which belong to different periods and come from different directions, converge: Alfred Lodge was a worthy member of the eminent family to which he belonged; his long life was a useful one, and he was a lovable man who was happy in being well loved.

E. H. N.

\section{Prof. Otto Warburg}

Prof. O. Warburg, who was well known as a botanist, was born in Hamburg in 1859. He travelled extensively for scientific investigation before being appointed lecturer in botany at the University of Berlin in 1891, later becoming professor in the Oriental seminary in Berlin.

Besides taking a very active interest in Zionism and affairs relating to colonization in Palestine, Warburg was the author of numerous botanical papers, particularly relating to tropical agriculture and economic botany. He was joint founder of the Tropenpflanzer, and was editor from its inception in 1897 until 1922, when he was succeeded by Dr. Busse. He was much interested in rubber plants and made an intensive study of the genus Ficus, par. ticularly the African species, of which he described a great number, and he published, conjointly with Dr. De Wildeman, an enumeration of the Ficus of the Belgian Congo. His book "Die Muskatnus" (nutmegs) is a comprehensive account published in 1897, and still a standard work on the subject, and in the same year he issued a monograph of the family Myristicaceæ. For Engler's Pflanzenreich" he was responsible for the screw pines (Pandanaceæ).

In his later life, Warburg devoted most of his time to the world Zionist movement, of which he became president in 1911. After the Great War, he was appointed head of the Agricultural Experimental Station in Palestine, being one of the founders, and he was also the director of the Institute of Natural History at the Hebrew University, Jerusalem. He was a man of great charm and of a retiring and scholarly disposition, and was revered by all sections. of the Zionist movement.

WE regret to announce the following deaths :

Prof. W. H. Pickering, emeritus professor of astronomy in the Harvard College Observatory, aged seventy-nine years.

Dr. Carlotta J. Maury, palæontologist in the Brazilian Survey, formerly professor of zoology and geology in the Huguenot University College, South Africa, on January 3, aged sixty-four years. 